\title{
Dietary supplementation of resveratrol suppresses colonic tumour incidence in 1,2-dimethylhydrazine-treated rats by modulating biotransforming enzymes and aberrant crypt foci development
}

\author{
Murugan Sengottuvelan and Namasivayam Nalini* \\ Department of Biochemistry and Biotechnology, Annamalai University, Annamalainagar - 608 002, Tamilnadu, India \\ (Received 14 October 2005 - Revised 21 February 2006 - Accepted 23 February 2006)
}

\begin{abstract}
Diet-induced changes in the activities of bacterial enzymes are known to play a role in colon cancer development. Resveratrol has been implicated as a protective agent in carcinogenesis. In the present study, the effect of resveratrol on the activities of faecal and colonic biotransforming enzymes such as $\beta$-glucuronidase, $\beta$-glucosidase, $\beta$-galactosidase, mucinase, nitroreductase and faecal sulfatase activity was assessed. The total number of aberrant crypt foci and their distribution in the proximal, medial and distal colon were observed in 1,2-dimethylhydrazine (DMH)-induced rats (group 3) and other treatment groups (groups 4-6). DMH (0.02 g/kg body weight) was given subcutaneously once a week for 15 consecutive weeks, and the experiment was terminated at 30 weeks. DMH-treated rats showed elevated levels of cancer-associated bacterial enzyme activities, whereas on resveratrol supplementation in three different regimens, rats showed lowered activities. Resveratrol supplementation throughout the experimental period (group 6) exerted a more pronounced effect $(P<0.01)$ by modulating the development of aberrant crypt foci and the activities of bacterial enzymes than did the other treatment regimens (groups 4 and 5). Thus, the present results demonstrate the inhibitory effect of resveratrol on DMH-induced colon carcinogenesis in rats.
\end{abstract}

Bacterial enzymes: Resveratrol: Aberrant crypt foci: Colon carcinogenesis

Chemoprevention - the prevention of cancer by the ingestion of chemical compounds that reduce the risk of carcinogenesis - is one of the direct ways to reduce morbidity and mortality (Sporn $\&$ Suh, 2000). Colorectal cancer is one of the most common cancers affecting men and women in the Western world (Young \& Le Leu, 2002). Although the aetiology of colon cancer is considered to be multifactorial and complex (Tajima et al. 1985), epidemiological studies suggest that dietary factors such as high intakes of fat and energy and a low proportion of unabsorbable fibres may be among the most important causal factors associated with colon cancer in man (Burkitt, 1993).

The induction of colonic tumours in mice and rats by 1,2dimethylhydrazine (DMH) is widely used as an experimental model for studies on the role of dietary factors in colon carcinogenesis (Goldin, 1998). High or repetitive doses of DMH result in a spectrum of antecedent and neoplastic changes analogous to those seen in man with regard to type of lesion and response to chemotherapy (Haase et al. 1973). Aberrant crypt foci (ACF), a preneoplastic change in the colonic mucosa, may represent a critical event in the stepwise progression of colon cancer. The study of premalignant hyperproliferative lesions and of aberrant crypts is crucial for understanding the progression of early changes to malignancy in the pathogenesis of colon cancer (Bird, 1987).

A wide range of compounds has been tested for possible chemopreventive activity (Morse \& Stoner, 1993). Dietary effects may be mediated through changes in the composition of endogenous compounds secreted into the gut as well as the composition of intestinal microflora (Burkitt, 1993). The intestinal microflora may play a significant role in colon carcinogenesis (Simon \& Gorbach, 1984). Differences in the composition and concentrations of some faecal bacteria were initially reported to be low, compared with high-risk colon cancer groups (Hill et al. 1971). More recently, their metabolic role has become better appreciated in chemically induced colon tumours. For example, the activation of procarcinogen to carcinogen (e.g. cycasin, the $\beta$-glucoside of methylazoxymethanol) is possibly mediated by bacterial enzymes (e.g. $\beta$-glucosidase). Other enzymes such as $\beta$-glucuronidase and $\beta$-galactosidase are also expressed in high levels in the intestinal tract of mammals, both on mucosal tissue and in the bowel flora (Laqueur \& Spatz, 1968), and also play a role in the metabolic activation of various xenobiotics.

Mucinase, a bacterial enzyme that hydrolyses the protective mucus layer, is of interest as it may alter the permeability and barrier function of the colon (Shiau \& Ong, 1992). The importance of nitroreductase in the absorption and activation of several environmental mutagens has been demonstrated in vivo, and there is evidence for the direct involvement of nitroreductase in colon carcinogenesis (Johansson et al. 1997). Faecal sulfatase activity is also considered in the desulfation of conjugated toxins and in the degradation of sulfated 
mucins. These enzymes are known to be agents of human disease. Thus, the products of colonic bacterial metabolism are in many cases associated with detrimental effects on the host and in particular may lead to the initiation and/or promotion of tumourigenesis (Reddy et al. 1992).

The effect of dietary compounds on DMH-retoxifying bacterial enzymes is thought to influence tumour development, and they have been extensively used to test the influence of dietary factors on colon carcinogenesis. Resveratrol (3,5,4'-trihydroxy-trans-stilbene; Fig. 1) is a polyphenolic compound present in seventy different varieties of plant species, including grapes, peanuts and mulberries. Resveratrol is currently available as a nutraceutical and is sold as an unregulated product in health food stores (Ector et al. 1996). The compound exhibits a variety of useful biological properties (Kimura et al. 1983), including antibacterial (Chan, 2002) and antifungal (Jeandet et al. 2002) effects. This triphenolic stilbene also has strong antioxidant and anti-inflammatory activities associated with chemopreventive properties (Miller \& Rice-Evans, 1995). Resveratrol has been suggested as a possible cancer chemopreventive agent on the basis of inhibitory effects on tumour initiation, promotion and progression (Jang et al. 1997).

Several studies have reported the differences between germfree and conventional animals with regard to the incidence, latency and histology of spontaneous and chemically induced tumours. Previous studies from our laboratory have shown that natural plant products such as coconut cake (Nalini et al. 2004), black pepper, cumin (Nalini et al. 1998) and ginger (Manju \& Nalini, 2005) effectively modulate colon carcinogenesis, which is paralleled by a decrease in bacterial enzyme activities. In the present study, we have investigated ACF development and the activities of faecal and colonic enzymes in DMH-induced rat colon carcinogenesis during resveratrol treatment in three regimens (initiation, post-initiation and entire period).

\section{Materials and methods}

\section{Animals and animal husbandry}

Male adult Wistar rats of body weight $120-150 \mathrm{~g}$ were obtained from the Central Animal House, Rajah Muthiah Medical College, Annamalai University, Annamalainagar, India, and were acclimatised to the control diet for 1 week. Animals were maintained as per the principles and guidelines of the Ethical Committee for Animal Care of Annamalai University in accordance with the Indian National Law on Animal Care and Use (Reg. No. 160/1999/CPCSEA).

The animals were housed four per cage in polypropylene cages with a wire mesh top and a hygienic bed of husk in a

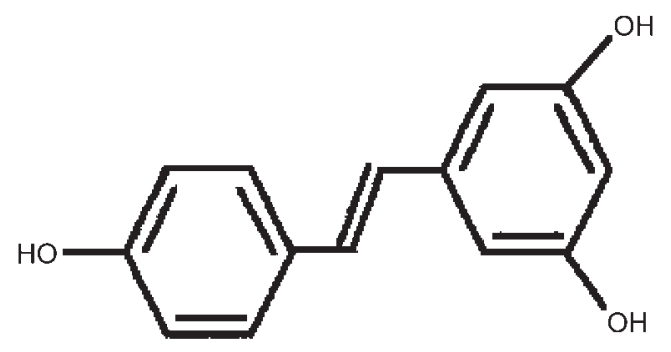

Fig. 1. Chemical structure of resveratrol. specific-pathogen-free animal room under controlled conditions of a $12 \mathrm{~h}$ light-dark cycle, with a temperature of $24 \pm 2{ }^{\circ} \mathrm{C}$ and a relative humidity of $65 \%$ until the end of the experimental period. The animals were maintained on commercial pellet diet (Hindustan Lever Ltd, Mumbai, India) and tap water ad libitum throughout the experimental period. Per $\mathrm{kg}$, the diet comprised $177 \mathrm{~g}$ proteins, $42 \mathrm{~g}$ fat, $505 \mathrm{~g}$ carbohydrates, $34 \mathrm{~g}$ fibre, $67 \mathrm{~g}$ minerals and $17 \mathrm{~g}$ vitamins.

\section{Chemicals}

DMH, methylene blue, $p$-nitrophenyl- $\beta$-D-glucuronide, $p$-nitrophenyl- $\beta$-D-glucopyranoside, $\quad p$-nitrophenyl- $\beta$-Dgalactopyranoside, porcine stomach mucin (type-III), $p$-nitrocatechol sulfate, $p$-nitrobenzoic acid and trans-resveratrol were purchased from Sigma Chemical Company (St Louis, $\mathrm{MO}$, USA). All other chemicals were obtained from $\mathrm{Hi}$ Media Laboratories (Mumbai, India).

\section{Carcinogen administration}

All animals in groups 3-6 received DMH $0.02 \mathrm{~g} / \mathrm{kg}$ body weight via injection once a week subcutaneously for the first 15 weeks. Prior to injection, DMH was dissolved in EDTA $(1 \mathrm{mM})$, the $\mathrm{pH}$ was adjusted to 6.5 with $\mathrm{NaOH}(1 \mathrm{~mm})$ and the solution was used immediately.

\section{Administration of chemopreventive agent}

Owing to its low solubility in water, trans-resveratrol $(0.008 \mathrm{~g} / \mathrm{kg}$ body weight) was suspended in $1 \%(\mathrm{w} / \mathrm{v})$ carboxymethylcellulose in water and given orally using an intragastric tube. The preparation and administration of trans-resveratrol were performed in dim light to avoid its isomerisation to the cis form.

\section{Experimental design}

Rats were assorted into experimental groups (sixteen per group; eight for ACF analysis and eight for enzyme activity studies), using a randomisation process designed to ensure comparable initial body weight in all the study protocols. Food consumption and animal body weight were monitored weekly throughout the experimental period of 30 weeks. Details and a schematic representation of the experimental design are shown in Table 1 and Fig. 2, respectively.

\section{Animal autopsy and tissue preparation}

At the end of 30 weeks, the diet was withdrawn $12 \mathrm{~h}$ before autopsy, and the animals were killed under anesthaesia (intraperitoneal administration of ketamine hydrochloride, $30 \mathrm{mg} / \mathrm{kg}$ body weight) by cervical dislocation between 08.00 and 10.00 hours. Resveratrol supplementation was withdrawn $24 \mathrm{~h}$ before autopsy from animals in groups 2, 5 and 6 . The abdominal cavities were examined to reveal any macroscopic changes.

\section{Preparation for aberrant crypt foci counting}

The colon was processed as follows for the determination of ACF (Bird, 1995). The entire colon (from caecum to anus) was removed and washed thoroughly with $0.9 \%(\mathrm{w} / \mathrm{v}) \mathrm{NaCl}$, cut longitudinally, laid flat on a polystyrene board and fixed 
Table 1. Details of the experimental design

\begin{tabular}{|c|c|}
\hline Group & Treatment \\
\hline Group 1 (CON) & $\begin{array}{l}\text { Rats received basal diet along with intragastric intubation of } 1 \%(w / v) \text { carboxymethylcellulose in water, } \\
\text { throughout the experiment }\end{array}$ \\
\hline Group 2 (CON + RES) & $\begin{array}{l}\text { Rats received basal diet }+ \text { RES }(0.008 \mathrm{~g} / \mathrm{kg} \text { body weight) suspended in } 1 \%(\mathrm{w} / \mathrm{v}) \text { carboxymethylcellulose in water, } \\
\text { orally every day throughout the experiment }\end{array}$ \\
\hline Group 3 (DMH) & $\begin{array}{l}\text { Rats were administered } \mathrm{DMH} \text { (carcinogen) } 0.02 \mathrm{~g} / \mathrm{kg} \text { body weight subcutaneously once a week } \\
\text { for first } 15 \text { weeks }\end{array}$ \\
\hline Group $4 \mathrm{DMH}+\mathrm{RES}(\mathrm{I})$ & $\begin{array}{l}\text { The animals were supplemented with RES every day starting } 2 \text { weeks before carcinogen } \\
\text { treatment for the first } 15 \text { weeks (initiation }-\mathrm{I} \text { ) }\end{array}$ \\
\hline Group 5 DMH + RES (PI) & $\begin{array}{l}\text { The animals were supplemented with RES } 2 \mathrm{~d} \text { after the last injection of the carcinogen } \\
\text { and continued until the end of the experiment (post-initiation - PI) }\end{array}$ \\
\hline Group 6 DMH + RES (EP) & $\begin{array}{l}\text { The animals were supplemented with RES from the day of carcinogen treatment and } \\
\text { continued until the end of the entire experimental period of } 30 \text { weeks (entire period - EP) }\end{array}$ \\
\hline
\end{tabular}

CON, control; RES, trans-resveratrol; DMH, 1,2-dimethylhydrazine.

with $10 \%(\mathrm{v} / \mathrm{v})$ buffered formaldehyde solution overnight. The colon was then stained with $0.2 \%(\mathrm{w} / \mathrm{v})$ methylene blue for 2-3 min in saline in order to identify the ACF. Mucosal ACF were counted using a light microscope ( $\times 40$ magnification). The ACF were classified as small (one to three crypts), medium (four to six crypts) or large (more than six crypts) by the number of crypts per foci. The distribution pattern and total number of ACF were calculated as the sum of the small, medium and large ACF.

\section{Mucosal and faecal sample preparation}

The caecal contents $(100 \mathrm{mg} / \mathrm{l})$ and mucosal scrapings $(100 \mathrm{~g} / \mathrm{l})$ were immediately suspended in $0 \cdot 1 \mathrm{M}$-phosphate buffer $(\mathrm{pH} 7 \cdot 0)$. Caecal and mucosal suspensions were homogenised for $3 \mathrm{~min}$ using a Teflon homogeniser (Remi Instruments, India) and filtered through a $0.5 \mathrm{~mm}$ mesh. The samples were then centrifuged for $10 \mathrm{~min}$ at $5000 \mathrm{~g}$ at $4^{\circ} \mathrm{C}$, and aliquots of the suspensions were used immediately.

\section{Enzyme assays}

The activities of faecal and mucosal $\beta$-glucuronidase, $\beta$-glucosidase and $\beta$-galactosidase (George et al. 2000)

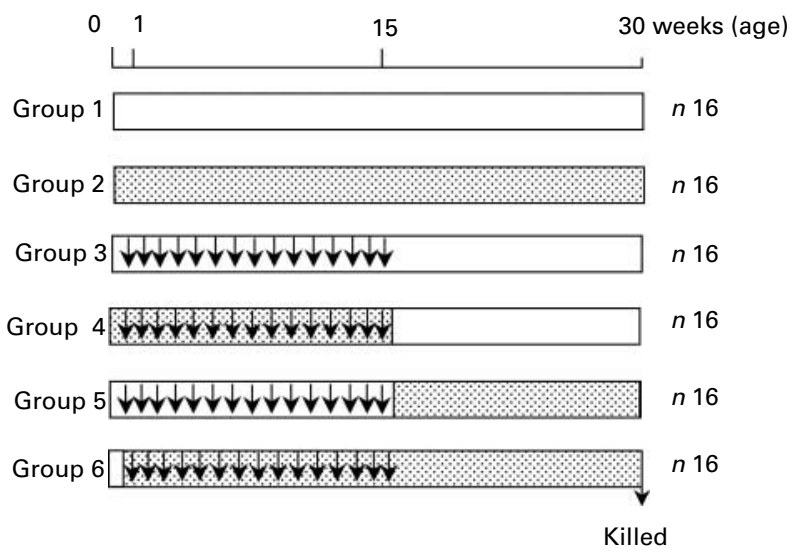

Fig. 2. Schematic representation of the experimental design. For details of the procedure, see p. 146, also Table 1. $\square$, Standard pellet diet; 䓒, standard pellet diet + resveratrol $(0.008 \mathrm{~g} / \mathrm{kg}$ body weight, orally every day); $\nabla$, standard pellet diet $+1,2$-dimethylhydrazine (DMH $0.02 \mathrm{~g} / \mathrm{kg}$ body weight subcutaneously) once a week for 15 consecutive weeks; $\downarrow$, DMH injections. were assayed using $p$-nitrophenyl- $\beta$-D-glucopyranoside $(3 \mathrm{~mm}), p$-nitrophenyl- $\beta$-D-glucoside $(3 \mathrm{~mm})$ and $p$-nitrophenyl- $\beta$-D-galactopyranoside $(3 \mathrm{~mm})$ respectively, as substrates. $\beta$-Glucuronidase, $\beta$-glucosidase and $\beta$-galactosidase activities were expressed as micromoles of $p$-nitrophenol liberated per minute per gram wet weight of caecal contents and micromoles of $p$-nitrophenol liberated per hour per gram protein. Faecal and mucosal mucinase enzyme activities were determined by the method of Shiau \& Chang (1983), using porcine stomach mucin (type III) as substrate. Mucinase activities were expressed as micromoles of glucose liberated per minute per gram wet weight of caecal contents and micromoles of glucose liberated per hour per gram of protein.

Faecal and mucosal nitroreductase enzyme activities were determined by the method of Bratton \& Marshall (1939) using $p$-nitrobenzoic acid as substrate. The nitroreductase activities were expressed as micromoles of $p$-aminobenzoic acid liberated per minute per gram of caecal contents and micromoles of $p$-aminobenzoic acid liberated per hour per gram of protein. Faecal sulfatase enzyme activity was determined by the method described by Rowland et al. (1998) using $p$-nitrocatechol sulfate as substrate and was expressed as micromoles of $p$-nitrocatechol liberated per minute per gram of wet weight of caecal contents.

\section{Protein assay}

Protein determination was done in triplicate based on the method of Lowry et al. (1951) using bovine serum albumin as the standard.

\section{Statistical analysis}

Data were analysed by one-way ANOVA, and significant differences between treatment groups were evaluated by Duncan's Multiple Range Test. The results were considered statistically significant at $P<0 \cdot 05$. All statistical analyses were made using the SPSS 11.0 software package (SPSS, Tokyo, Japan).

\section{Results}

Tumour analysis

Table 2 summarises the incidence, size and location of tumours in the experimental groups. Fig. 3 illustrates the 
Table 2. Effect of 1,2-dimethylhydrazine and resveratrol on the colonic tumour incidence, size and locationt (Mean values and standard deviations)

\begin{tabular}{|c|c|c|c|c|c|c|c|c|c|c|}
\hline \multirow[b]{2}{*}{ Group } & \multirow[b]{2}{*}{$\begin{array}{l}\text { Number } \\
\text { of rats }\end{array}$} & \multirow[b]{2}{*}{$\begin{array}{l}\text { Number of } \\
\text { tumour-bearing rats }\end{array}$} & \multirow[b]{2}{*}{$\begin{array}{c}\text { Tumour } \\
\text { incidence } \neq(\%)\end{array}$} & \multicolumn{3}{|c|}{$\begin{array}{c}\text { Number of } \\
\text { tumours in } \\
\text { tumour-bearing } \\
\text { rats }\end{array}$} & \multicolumn{2}{|c|}{$\begin{array}{l}\text { Mean tumour } \\
\text { size }\left(\mathrm{mm}^{2}\right)\end{array}$} & \multicolumn{2}{|c|}{$\begin{array}{l}\text { Tumour } \\
\text { location }\end{array}$} \\
\hline & & & & 1 & 2 & 3 & Mean & SD & $\begin{array}{l}\text { Proximal } \\
\text { colon }\end{array}$ & $\begin{array}{l}\text { Distal } \\
\text { colon }\end{array}$ \\
\hline CON & 16 & 0 & 0 & 0 & 0 & 0 & 0 & & 0 & 0 \\
\hline $\mathrm{DMH}$ & 16 & $14^{a}$ & $87^{a}$ & 7 & 3 & 2 & $26 \cdot 84^{a}$ & 2.49 & 7 & 12 \\
\hline DMH + RES (I) & 16 & $9^{b}$ & $56^{b}$ & 5 & 2 & 1 & $25 \cdot 22^{a}$ & $2 \cdot 23$ & 4 & 8 \\
\hline $\mathrm{DMH}+\mathrm{RES}(\mathrm{PI})$ & 16 & $7^{c}$ & $44^{c}$ & 7 & 1 & - & $20 \cdot 21^{b}$ & 1.99 & 3 & 6 \\
\hline $\mathrm{DMH}+\mathrm{RES}(\mathrm{EP})$ & 16 & $4^{d}$ & $25^{d}$ & 4 & - & - & $14 \cdot 07^{c}$ & 1.25 & 0 & 4 \\
\hline
\end{tabular}

CON, control; DMH, 1,2-dimethylhydrazine; RES, trans-resveratrol; I, initiation; PI, post-initiation; EP, entire period.

a,b,c,d Mean values within a column with unlike superscript letters were significantly different $(P<0.05)$.

†For details of the procedures, see Materials and methods (pp. 146-148).

$\ddagger$ (Number of tumour-bearing rats/total number of rats in each group) $\times 100$.

number of tumours per tumour-bearing rat (tumour burden per animal per group) for each group. A significant reduction in tumour number, incidence and size was observed in all resveratrol-treated rats (groups 4-6), compared with the rats treated with $\mathrm{DMH}$ alone (group 3). Among the treatment groups, a marked suppression in tumour development was observed in those animals treated with resveratrol throughout the entire 30-week experimental period (group 6). In addition, the photomicrographs of the colon in control and experimental groups (Fig. 4) showed that entire-period treatment regimen was more effec-

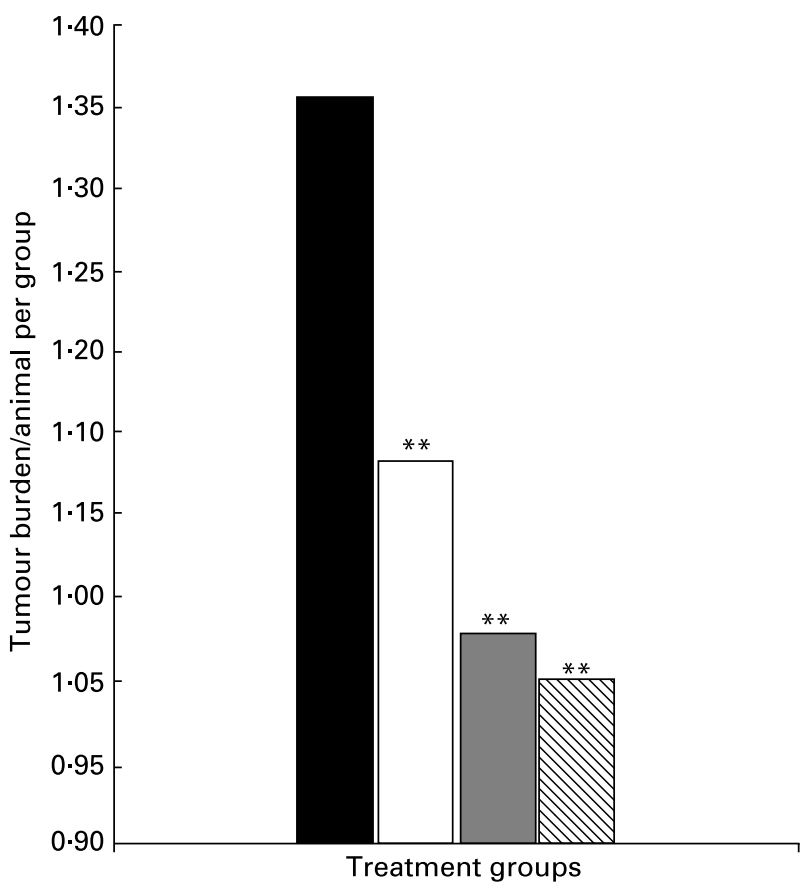

Fig. 3. Effect of resveratrol (RES) treatment on 1,2-dimethylhydrazine $(\mathrm{DMH})$-induced tumour burden per animal per group. $\square, \mathrm{DMH} ; \square, \mathrm{DMH}+$ RES (I); $\square, \mathrm{DMH}+\mathrm{RES}(\mathrm{PI}) ; \mathbb{N}, \mathrm{DMH}+\mathrm{RES}(\mathrm{EP})$. For details of the procedure, see Materials and methods (pp. 146-148). ${ }^{* *}$ Mean values were significantly different from those of the $\mathrm{DMH}$-treated group $(P<0.01)$. tive in suppressing the histopathological lesions induced by $\mathrm{DMH}$.

\section{Aberrant crypt foci development}

Table 3 depicts the number and distribution of ACF in different regions of colon. At the end of 30 weeks, a significant reduction in the total number of ACF was observed in all three treatment regimens (groups 4-6) compared with the rats treated with DMH alone (group 3). The statistically significant reduction in the total number of ACF was higher in the entire-period regimen (group 6; $P<0 \cdot 01$ ).

Table 4 shows the categories of small, medium and large ACF in the proximal, medial and distal regions of colon. The trend was similar to the distribution of ACF (Table 3).

\section{Faecal enzyme activities}

Table 5 summarises the activities of $\beta$-glucuronidase, $\beta$-glucosidase, $\beta$-galactosidase, mucinase and nitroreductase in fresh faecal samples. The activities of these enzymes were increased two to three times in the DMH-treated rats (group 3) compared with the control rats (group 1). The activities were significantly reduced in all resveratrol-supplemented rats (groups 4-6) compared with rats treated with $\mathrm{DMH}$ alone (group 3). Furthermore, there was a significantly greater reduction in $\beta$-glucuronidase, $\beta$-glucosidase, $\beta$-galactosidase, mucinase and nitroreductase activities $(21 \%, 45 \%, 37 \%, 41 \%$ and $26 \%$, respectively) in animals treated with resveratrol for the entire period (group 6) compared with the other resveratrol-treated rats (groups 4 and 5).

\section{Faecal sulfatase activity}

Fig. 5 shows the faecal sulfatase activity following resveratrol administration in different treatment groups. In carcinogen-treated rats (group 3), mean activities of the enzyme were elevated two fold compared with the control rats (group 1). In addition, there was a significant reduction 

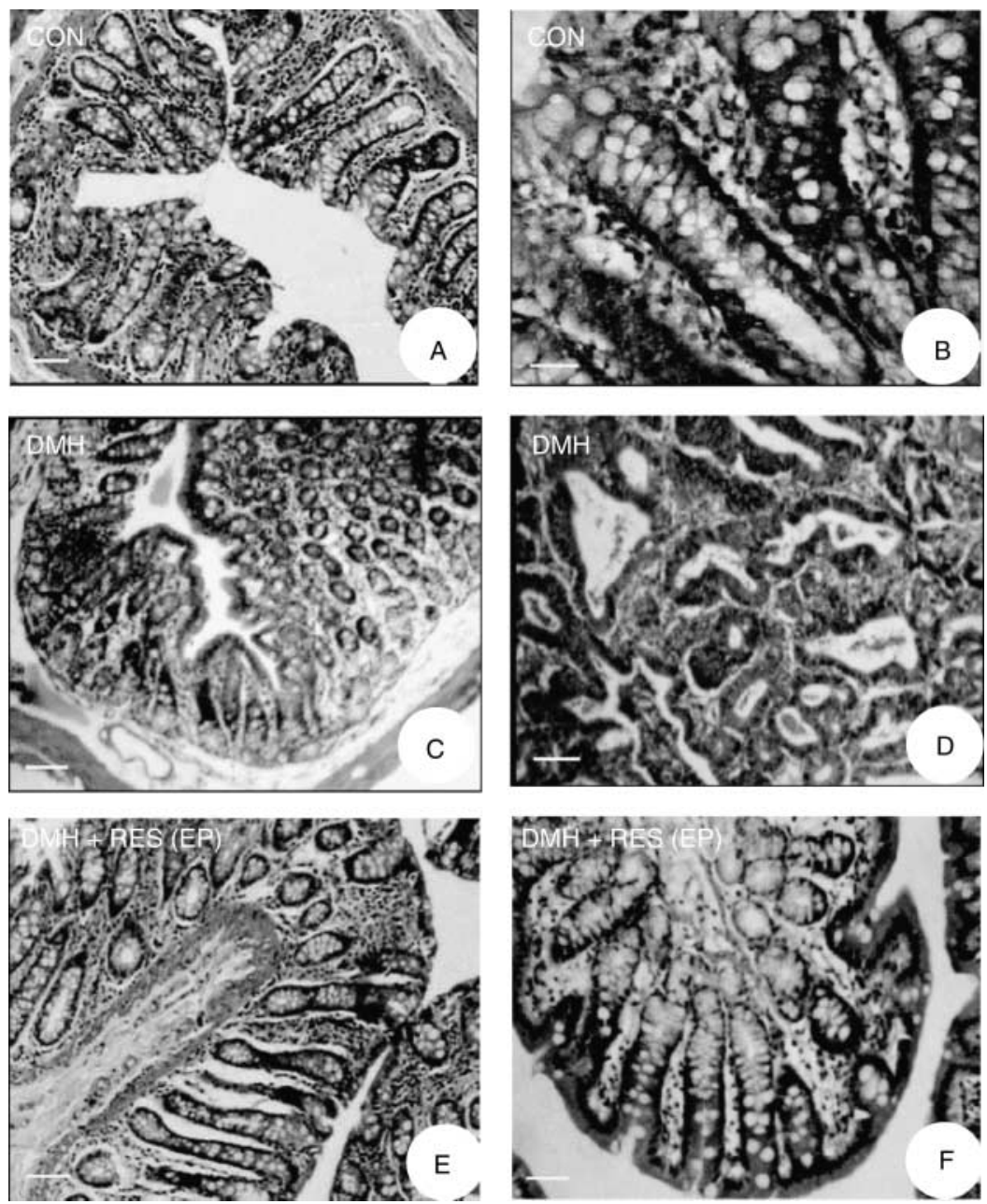

Fig. 4. Photomicrographs of rat colon tissue stained with haematoxylin and eosin in the control (CON) and experimental (DMH, 1,2-dimethylhydrazine; RES, transresveratrol; EP, entire period) groups. (A) [CON] Normal colonic mucosa. The mucosal crypts, lamina propria and muscularis mucosa were well oriented $(\mathrm{bar}=25 \mu \mathrm{m})$. (B) [CON] Shows the well-oriented columnar epithelium lining of the crypt (bar $=80 \mu \mathrm{m})$. (C) [DMH] Colon of a DMH-treated rat showing irregular disposition of the crypts, reduction of the intercryptic spaces and lymphoid-glandular complexes with severe inflammatory cell infiltrations (bar $=25 \mu \mathrm{m})$. (D) [DMH] $\mathrm{DMH}$-treated colon of rat showing severe epithelial dysplasia with complete loss of polarity and randomly placed nuclei $(\mathrm{bar}=80 \mu \mathrm{m})$. (E) $[\mathrm{DMH}+\mathrm{RES}(\mathrm{EP})] \mathrm{The}$ mucosal crypts, lamina propria and muscularis mucosae were well oriented, with scattered inflammatory cell infiltration $($ bar $=25 \mu \mathrm{m})$. $(\mathrm{F})[\mathrm{DMH}+\mathrm{RES}(\mathrm{EP})] \mathrm{A}$ normal mucosal layer with regular crypts (bar $=40 \mu \mathrm{m})$

in the faecal sulfatase activity in animals treated with resveratrol during the initiation and post-initiation regimens $(P<0 \cdot 05)$, the entire-period treatment group (group 6) showing a strong inhibition of sulfatase activity $(P<0 \cdot 01)$.

\section{Colonic mucosal enzyme activities}

Table 6 presents the activities of colonic mucosal enzymes. After 30 weeks, the colonic mucosal enzymes such as $\beta$-glucuronidase, $\beta$-glucosidase, $\beta$-galactosidase, mucinase and

Table 3. Effect of resveratrol treatment on total and regional distribution of aberrant crypt foci† (Mean values and standard deviations)

\begin{tabular}{|c|c|c|c|c|c|c|c|c|}
\hline & \multicolumn{2}{|c|}{ DMH } & \multicolumn{2}{|c|}{$\begin{array}{c}\mathrm{DMH}+\mathrm{RES} \\
\text { (I) }\end{array}$} & \multicolumn{2}{|c|}{$\begin{array}{c}\mathrm{DMH}+\mathrm{RES} \\
\quad(\mathrm{PI})\end{array}$} & \multicolumn{2}{|c|}{$\begin{array}{c}\mathrm{DMH}+\mathrm{RES} \\
\text { (EP) }\end{array}$} \\
\hline & Mean & SD & Mean & SD & Mean & SD & Mean & SD \\
\hline Total count of aberrant crypt foci & $100 \cdot 3^{a}$ & $10 \cdot 2$ & $50 \cdot 4^{\mathrm{b}}$ & $5 \cdot 3$ & $39.4^{\mathrm{C}}$ & 5.4 & $28 \cdot 5^{\mathrm{d}}$ & $5 \cdot 1$ \\
\hline Proximal colon & $11 \cdot 7^{\mathrm{a}}$ & 0.9 & $6 \cdot 7^{\mathrm{b}}$ & 0.6 & $4 \cdot 2^{\mathrm{c}}$ & $1 \cdot 3$ & $1.7^{\mathrm{d}}$ & 0.6 \\
\hline Medial colon & $30.1^{a}$ & $3 \cdot 2$ & $14 \cdot 3^{b}$ & 1.6 & $12 \cdot 3^{\mathrm{C}}$ & 1.5 & $10 \cdot 2^{d}$ & 1.6 \\
\hline Distal colon & $58 \cdot 5^{\mathrm{a}}$ & $6 \cdot 1$ & $29 \cdot 4^{a}$ & $3 \cdot 1$ & $22 \cdot 9^{\mathrm{bc}}$ & $2 \cdot 6$ & $16 \cdot 6^{c}$ & $2 \cdot 9$ \\
\hline
\end{tabular}

$\mathrm{DMH}, 1$,2-dimethylhydrazine; RES, trans-resveratrol; I, initiation; PI, post-initiation; EP, entire period. $a, b, c, d$ Mean values within a row with unlike superscript letters were significantly different $(P<0 \cdot 01)$. †For details of the procedure, see Materials and methods (pp. 146-148). 
Table 4. Effect of resveratrol treatment on category of aberrant crypt foci in the proximal, medial and distal colon† (Mean values and standard deviations)

\begin{tabular}{|c|c|c|c|c|c|c|c|c|}
\hline \multirow{2}{*}{$\begin{array}{l}\text { Category of aberrant } \\
\text { crypt foci }\end{array}$} & \multicolumn{2}{|c|}{$\mathrm{DMH}$} & \multicolumn{2}{|c|}{$\mathrm{DMH}+\mathrm{RES}(\mathrm{I})$} & \multicolumn{2}{|c|}{$\mathrm{DMH}+\mathrm{RES}(\mathrm{PI})$} & \multicolumn{2}{|c|}{$\mathrm{DMH}+\mathrm{RES}(\mathrm{EP})$} \\
\hline & Mean & SD & Mean & SD & Mean & SD & Mean & SD \\
\hline Small & 9.2 & 0.6 & $4 \cdot 1$ & 0.3 & $3 \cdot 2$ & 1.0 & $1 \cdot 0$ & 0.4 \\
\hline Medium & 1.5 & 0.2 & 1.4 & 0.2 & 0.7 & 0.2 & 0.7 & 0.2 \\
\hline Large & $1 \cdot 0$ & 0.1 & $1 \cdot 2$ & 0.1 & 0.3 & 0.1 & - & - \\
\hline \multicolumn{9}{|l|}{ Medial } \\
\hline Medium & $25 \cdot 6$ & 3.5 & $10 \cdot 1$ & 0.5 & $10 \cdot 8$ & 1.6 & $4 \cdot 2$ & 0.5 \\
\hline Large & $17 \cdot 6$ & 1.0 & $6 \cdot 0$ & 0.7 & $5 \cdot 9$ & 0.7 & $4 \cdot 1$ & 0.9 \\
\hline \multicolumn{9}{|l|}{ Distal } \\
\hline Small & $11 \cdot 1$ & $1 \cdot 2$ & $8 \cdot 3$ & 1.0 & $8 \cdot 2$ & 1.0 & $2 \cdot 8$ & 0.4 \\
\hline Medium & $15 \cdot 3$ & 1.9 & $5 \cdot 0$ & 0.4 & $2 \cdot 6$ & 0.3 & $5 \cdot 3$ & 0.9 \\
\hline Large & 3.7 & 0.1 & 1.0 & 0.2 & 1.5 & 0.2 & $2 \cdot 1$ & 0.3 \\
\hline
\end{tabular}

$\mathrm{DMH}, 1$,2-dimethylhydrazine; RES, trans-resveratrol; I, initiation; PI, post-initiation; EP, entire period.

†For details of the procedure, see Materials and methods (pp. 146-148).

nitroreductase activities were two- to threefold higher in the DMH-treated rats (group 3) compared with the control rats (group 1), whereas the activities of these enzymes were significantly reduced in rats administered DMH and supplemented with resveratrol (groups 4-6) compared with the unsupplemented DMH-treated rats (group 3). Significantly greater reductions in the percentage of $\beta$-glucuronidase, $\beta$-glucosidase, $\beta$-galactosidase, mucinase and nitroreductase activities $(35 \%, 42 \%, 36 \%, 37 \%$ and $39 \%$, respectively) were observed in rats treated with resveratrol during the entire period (group 6) of the study.

\section{Discussion}

Chemoprevention embraces the concept that non-carcinogenic synthetic chemicals or naturally occurring products can inhibit the process of carcinogenesis (Wattenberg, 1985). The variety of compounds that inhibit the formation of carcinogens has been documented in various investigations. Blocking agents are inhibitors of tumour initiation, whereas suppressing agents are inhibitors of tumour promotion/progression.
Many well-characterised chemopreventive agents act at one or more steps during both the tumour initiation and promotion/progression stages (Morse \& Stoner, 1993).

Trans-resveratrol is a phytochemical found in various foods such as grapes, peanuts and red wine, and it is one of the active ingredients of traditional Japanese and Chinese ko-jo-kon medicine, which uses the dried powdered roots of Polygonum cuspidatum (SIEB. ET ZUCC.) for the treatment of human fungal, inflammation, hypertension, allergic and lipid diseases (Nonomura et al. 1963). It is also a known potential chemopreventive agent (Jang et al. 1997). In the present study, we have carried out a detailed and comprehensive study of resveratrol on bacterial enzymes and its association with colorectal cancer.

The reduction in tumour incidence on resveratrol supplementation could be due to a delay in the initiation, promotion or progression process, or could be mediated through an enhanced repair mechanism or remodelling of preneoplastic lesions (Thurnherr et al. 1973). Although the early evolution of colon carcinogenesis is not completely understood, dysplastic crypts have been observed and interpreted as early lesions leading to colonic cancer. Dysplastic crypts

Table 5. Effect of resveratrol treatment on faecal bacterial enzymes† (Mean values and standard deviations)

\begin{tabular}{|c|c|c|c|c|c|c|c|c|c|c|}
\hline \multirow[b]{2}{*}{ Treatment group } & \multicolumn{2}{|c|}{$\begin{array}{c}\beta \text {-Glucuronidase } \\
\text { ( } \mu \text { mol } p \text {-nitrophenol/ } \\
\text { min per g caecal } \\
\text { contents } \\
\text { (wet weight)) }\end{array}$} & \multicolumn{2}{|c|}{$\begin{array}{l}\beta \text {-Glucosidase }(\mu \mathrm{mol} \\
p \text {-nitrophenol } / \mathrm{min} \\
\text { per g caecal contents } \\
\text { (wet weight)) }\end{array}$} & \multicolumn{2}{|c|}{$\begin{array}{l}\beta \text {-Galactosidase } \\
\text { ( } \mu \mathrm{mol} p \text {-nitrophe- } \\
\text { nol/min per g } \\
\text { caecal contents } \\
\text { (wet weight)) }\end{array}$} & \multicolumn{2}{|c|}{$\begin{array}{c}\text { Mucinase } \\
\text { ( } \mu \text { mol glucose/ } \\
\text { min per g caecal } \\
\text { contents } \\
\text { (wet weight)) }\end{array}$} & \multicolumn{2}{|c|}{$\begin{array}{l}\text { Nitroreductase } \\
\text { ( } \mu \mathrm{mol} p \text {-aminoben- } \\
\text { zoic acid/min per } \mathrm{g} \\
\text { caecal contents } \\
\text { (wet weight)) }\end{array}$} \\
\hline & Mean & SD & Mean & SD & Mean & SD & Mean & SD & Mean & SD \\
\hline $\mathrm{CON}$ & $17 \cdot 63^{a}$ & 1.63 & $46 \cdot 12^{a}$ & 4.28 & $26 \cdot 64^{a}$ & 2.47 & $2 \cdot 56^{a}$ & 0.23 & $20 \cdot 23^{a}$ & 1.88 \\
\hline $\mathrm{DMH}$ & $25 \cdot 69^{c}$ & 2.53 & $106 \cdot 78^{b}$ & $10 \cdot 53$ & $68.95^{\mathrm{b}}$ & $6 \cdot 80$ & $5 \cdot 36^{b}$ & 0.52 & $35 \cdot 67^{b}$ & 3.52 \\
\hline $\mathrm{DMH}+\mathrm{RES}(\mathrm{I})$ & $24 \cdot 25^{\mathrm{cd}}$ & $2 \cdot 16$ & $99 \cdot 79^{c}$ & 8.82 & $66 \cdot 50^{\mathrm{bc}}$ & 5.94 & $5 \cdot 00^{c}$ & 0.44 & $34 \cdot 19^{b}$ & 3.05 \\
\hline $\mathrm{DMH}+\mathrm{RES}(\mathrm{PI})$ & $23 \cdot 23^{d}$ & 2.07 & $77 \cdot 55^{d_{* *}}$ & $6 \cdot 92$ & $63.47^{c}$ & $5 \cdot 67$ & $4 \cdot 95^{c}$ & 0.44 & $33 \cdot 18^{b}$ & 2.96 \\
\hline $\mathrm{DMH}+\mathrm{RES}(\mathrm{EP})$ & $20 \cdot 24^{b * *}$ & 1.80 & $58.44^{\mathrm{e}_{* \star}}$ & $5 \cdot 22$ & $42 \cdot 35^{d_{* *}}$ & 3.78 & $3 \cdot 15^{\mathrm{d} * \star}$ & 0.28 & $26 \cdot 26^{\mathrm{c**}}$ & $2 \cdot 34$ \\
\hline
\end{tabular}

CON, control; DMH, 1,2-dimethylhydrazine; RES, trans-resveratrol; I, initiation; PI, post-initiation; EP, entire period.

$\mathrm{a}, \mathrm{b}, \mathrm{c}, \mathrm{d}, \mathrm{e}$ Mean values within a column with unlike superscript letters were significantly different $(P<0.05)$

${ }^{\star *}$ Mean values were significantly different from the DMH-treated group $(P<0.01)$.

†For details of the procedures, see Materials and methods (pp. 146-148). 


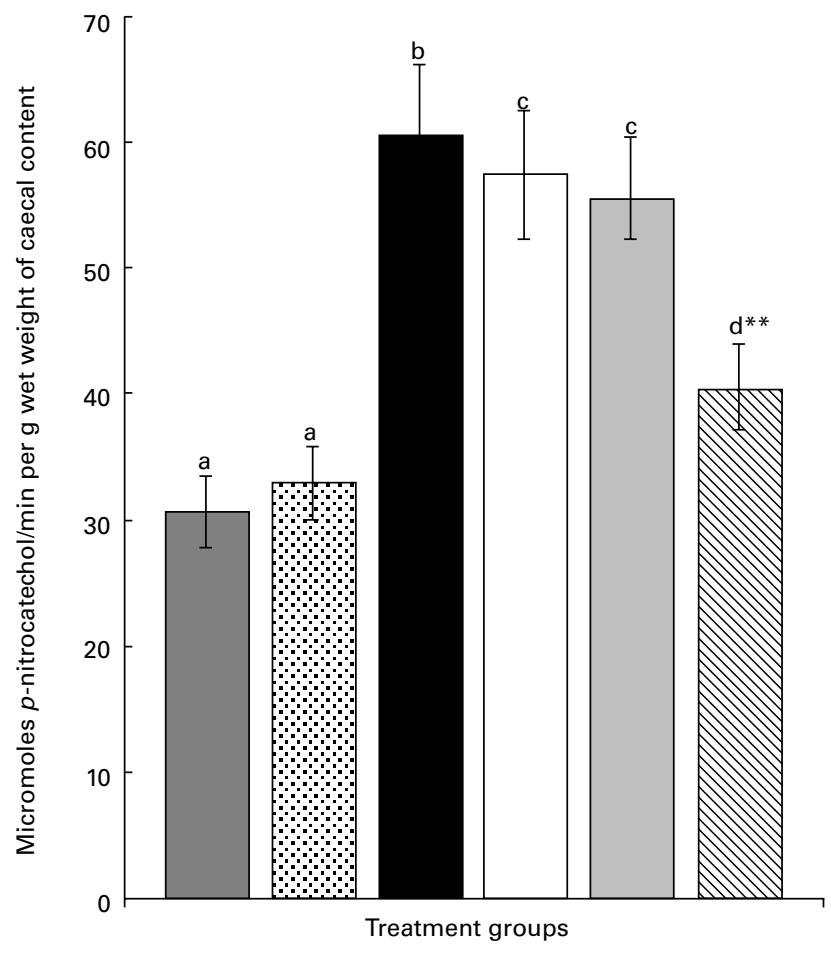

Fig. 5. Effect of resveratrol (RES) treatment on 1,2-dimethylhydrazine (DMH)induced faecal sulfatase activities (micromoles of $p$-nitrocatechol liberated per minute per gram of wet weight caecal contents). $\square$, CON; $\because \because$, CON + RES;

, DMH; $\square, \mathrm{DMH}+\mathrm{RES}(\mathrm{I}) ; \square, \mathrm{DMH}+\mathrm{RES}(\mathrm{PI}) ; \mathrm{N}, \mathrm{DMH}+\mathrm{RES}(\mathrm{EP})$. Values are means and with their standard deviations shown by vertical bars. For details of the procedure, see Materials and methods (pp. 146-148). $\mathrm{a}, \mathrm{b}, \mathrm{c}, \mathrm{d}$ Mean values were significantly different $(P<0 \cdot 05)$. ${ }^{\star \star}$ Mean values were significantly different from the DMH-treated group $(P<0.01)$.

have also been described in the colonic mucosa of patients with ulcerative colitis and familial polyposis, diseases characterised by a high risk of colon cancer (Riddell, 1984). ACF were considered to be biological precursors of colon cancer in rodents and man (Bird \& Good, 2000). In several studies, the total and regional distribution of ACF was used to predict the sensitivity and specificity of potential chemopreventive agents. Larger ACF (six or more aberrant crypts per focus) are considered more likely to progress into tumours (Bird \& Good, 2000), and in the present study, resveratrol feeding had a significant inverse influence on larger ACF formation in the distal colon. Schneider et al. (2001) have shown that the administration of resveratrol inhibits tumourigenesis and modulates host defence-related gene expression. Tessitore et al. (2000) also suggested that resveratrol inhibits the growth of colonic ACF and suppresses the progression of preneoplasia to malignant neoplasia.

Although the mechanisms involved in the protective effects against ACF formation are not clearly understood, the inhibitory action of resveratrol could be explained by its putative antioxidant properties, which have been found to inhibit DMH- and azoxymethane-induced colon carcinogenesis and DNA damage (Kawamori et al. 1995). An intriguing suggestion is that resveratrol feeding might reduce luminal mutation derived from $\mathrm{DMH}$, which could result in a reduction in tumour burden and ACF development.

It is interesting to note that resveratrol not only reduced the number of ACF, but also altered the distribution of ACF in the entire colon. The percentage of ACF in the distal colon decreased with an increase in the period of resveratrol treatment. ACF develop as early as $2-4$ weeks after carcinogen administration and appear predominantly in the medial colon during the early stages. As time progresses, however, ACF appear in the distal and proximal colon, and a proportion of ACF start to exhibit focal expansion and may contain one or a few crypts (Bird, 1995). Resveratrol supplementation for the entire period suppressed the formation of ACF in the distal colon, suggesting that resveratrol might intervene in the development of ACF at later time point. These findings suggest that resveratrol suppresses early events in colon carcinogenesis and also the formation of tumours.

A second plausible explanation for the reduction in tumour incidence and ACF development may be associated with the reduced activities of faecal and colonic mucosal enzymes such as $\beta$-glucuronidase, $\beta$-glucosidase, $\beta$-galactosidase, mucinase, nitroreductase and sulfatase on resveratrol supplementation for DMH-treated rats. Evidence from a wide range of sources supports the view that the colonic microflora play a significant role in the aetiology of colon cancer (George et al. 2004). In high-risk populations, increased expression of

Table 6. Effect of resveratrol treatment on colonic mucosal enzymes $\dagger$ (Mean values and standard deviations)

\begin{tabular}{|c|c|c|c|c|c|c|c|c|c|c|}
\hline \multirow[b]{2}{*}{ Treatment group } & \multicolumn{2}{|c|}{$\begin{array}{c}\beta \text {-Glucuronidase } \\
\text { ( } \mu \text { mol } p \text {-nitrophenol } \\
\text { /h per g protein) }\end{array}$} & \multicolumn{2}{|c|}{$\begin{array}{c}\beta \text {-Glucosidase } \\
\text { ( } \mu \text { mol } p \text {-nitrophenol } \\
\text { /h per g protein) }\end{array}$} & \multicolumn{2}{|c|}{$\begin{array}{c}\beta \text {-Galactosidase } \\
\text { ( } \mu \text { mol } p \text {-nitrophenol } \\
\text { /h per g protein) }\end{array}$} & \multicolumn{2}{|c|}{$\begin{array}{l}\text { Mucinase }(\mu \mathrm{mol} \\
p \text {-nitrophenol/h } \\
\text { per g protein) }\end{array}$} & \multicolumn{2}{|c|}{$\begin{array}{c}\text { Nitroreductase } \\
\text { ( } \mu \mathrm{mol} p \text {-nitrophe- } \\
\text { nol/h per g protein) }\end{array}$} \\
\hline & Mean & SD & Mean & SD & Mean & SD & Mean & SD & Mean & SD \\
\hline CON & $7 \cdot 58^{a}$ & 0.70 & $23 \cdot 46^{a}$ & 2.18 & $21 \cdot 22^{a}$ & 1.97 & $2 \cdot 00^{a}$ & 0.18 & $12 \cdot 17^{\mathrm{a}}$ & 1.13 \\
\hline $\mathrm{CON}+\mathrm{RES}$ & $8.09^{a}$ & 0.71 & $25 \cdot 14^{a}$ & $2 \cdot 22$ & $22 \cdot 06^{a}$ & 1.95 & $2 \cdot 06^{a}$ & 0.18 & $13 \cdot 04^{\mathrm{ab}}$ & $1 \cdot 15$ \\
\hline $\mathrm{DMH}$ & $15 \cdot 69^{b}$ & 1.54 & $65.53^{b}$ & $6 \cdot 46$ & $42 \cdot 77^{b}$ & $4 \cdot 22$ & $4.06^{b}$ & 0.40 & $23 \cdot 48^{c}$ & $2 \cdot 31$ \\
\hline DMH + RES (PI) & $12 \cdot 19^{\mathrm{C} \star \star}$ & 1.08 & $61 \cdot 46^{\mathrm{c}}$ & 5.49 & $31 \cdot 29^{d \star \star}$ & $2 \cdot 79$ & $3.72^{c}$ & 0.33 & $18 \cdot 22^{\mathrm{e} \star \star}$ & 1.62 \\
\hline $\mathrm{DMH}+\mathrm{RES}(\mathrm{EP})$ & $10 \cdot 16^{\mathrm{d} * *}$ & 0.90 & $38.54^{d \star *}$ & 3.44 & $27 \cdot 47^{\mathrm{e} *}$ & 2.45 & $2 \cdot 56^{d * *}$ & 0.22 & $14 \cdot 30^{\mathrm{b} * *}$ & $1 \cdot 27$ \\
\hline
\end{tabular}

CON, control; DMH, 1,2-dimethylhydrazine; RES, trans-resveratrol; I, initiation; PI, post-initiation; EP, entire period.

$\mathrm{a}, \mathrm{b}, \mathrm{c}, \mathrm{d}, \mathrm{e}$ Mean values within a column with unlike superscript letters were significantly different $(P<0.05)$

** Mean values were significantly different from the DMH-treated group $(P<0.01)$.

$\dagger$ For details of the procedures, see Materials and methods (pp. 146-148). 
intestinal mucosa $\beta$-glucuronidase, $\beta$-glucosidase and $\beta$-galactosidase has been documented (Reddy et al. 1978). In addition, it has been reported that colonisation with pathogenic bacterial species such as Escherichia coli enhances the progression of ACF (Rembacken et al. 1999). Furthermore, Rowland et al. (1983) have suggested that a reduction of bacterial enzyme activity is paralleled by a decreased frequency of ACF.

Epithelial mucins are a family of secreted and cell-surface glycoproteins expressed by epithelial tissues. Many human mucins genes appear to encode secreted mucins that protect and lubricate epithelial tissues by forming a layer of viscoelastic gel (Seregni et al. 1997). A change in mucinase activity is accompanied by a change in the rate of mucin degradation and a shift in the balance between mucin secretion and degradation (Eriyamremu \& Adamson, 1995). Enhanced degradation of the mucosal lining of the colonic epithelial cells (mucin) ensures a greater contact of the toxic carcinogen with the colonocytes. This may be accompanied by an increased susceptibility of the colonic cells to transformation (Goldin \& Gorbach, 1984).

Several other enzymes such as nitroreductase and sulfatase have also been implicated in the carcinogenic process, retoxifying and releasing carcinogens in the gastrointestinal tract (Gorbach \& Goldin, 1990). Nitroreductase and sulfatase are key enzymes responsible for metabolic activation of many procarcinogens, and sulfate conjugation is an important second-phase biotransformation reaction in mammals. Bacterial flora can hydrolyse many aromatic compounds to genotoxic metabolites by nitroreductase activities (Rhodes et al. 1985). The carcinogens, on becoming reduced, may be converted into highly reactive intermediates, which can in turn react with proteins and nucleic acids (Kinouchi et al. 1993). Faecal sulfatase activity is also considered in the desulfation of conjugated toxins and in the degradation of sulfated mucins. Changes in the expression of sulfated molecules such as mucins and other glycoconjugates have been demonstrated in transformed colon epithelial cells (Nieuw Amerongen et al. 1998).

The influence of diet on tumour development and its effect on DMH-retoxifying bacterial enzymes have been used extensively to test its influence on colon carcinogenesis (Shimotoyodome et al. 2000). The activities of these bacterial enzymes were significantly decreased following resveratrol treatment, especially when $0.008 \mathrm{~g} / \mathrm{kg}$ body weight was supplemented for the entire period. Naturally occurring phenolic compounds such as resveratrol retain antiproliferative, antioxidative, antibacterial and anti-inflammatory properties, which appear to contribute to their chemopreventive and chemoprotective activity (Gusman et al. 2001). Our data thus support the suggestion that, in addition to its cancer-chemopreventive effects in rodents, resveratrol merits further investigations as a cancer-chemoprotective agent in man.

\section{Acknowledgements}

Financial support from the Lady Tata Memorial Trust, Mumbai, in the form of a Senior Research Fellowship to M. S., is gratefully acknowledged.

\section{References}

Bird RP (1987) Observation and quantification of aberrant crypts in the murine colon treated with a colon carcinogen: preliminary findings. Cancer Lett 37, 147-151.

Bird RP (1995) Role of aberrant crypt foci in understanding the pathogenesis of colon cancer. Cancer Lett 93, 55-71.

Bird RP \& Good CK (2000) The significance of aberrant crypt foci in understanding the pathogenesis of colon cancer. Toxicol Lett 112-113, 395-402.

Bratton AC \& Marshall EK (1939) A new coupling component for sulfanilamide determination. $J$ Biol Chem 128, 537-550.

Burkitt DP (1993) Epidemiology of cancer of the colon and rectum. Dis Colon Rectum 36, 1071-1082.

Chan MM (2002) Antimicrobial effect of resveratrol on dermatophytes and bacterial pathogens of the skin. Biochem Pharmacol 63, 99-104.

Ector BJ, Magee JB, Hegwood CP \& Coign M (1996) Resveratrol concentration in muscadine berries, juice, pomace, purees, seeds and wines. Am J Enol Vitic 47, 57-62.

Eriyamremu GE \& Adamson I (1995) Alterations in rat colonic faeces exposed to an acute level of deoxycholate and fed on a Nigerian-like diet. Nutr Res 15, 869-880.

George SE, Nelson GM, Swank AE, Brooks LR, Bailey K, George M \& DeAngelo A (2000) The disinfection by-products dichloro-, dibromo-, and bromochloroacetic acid impact intestinal microflora and metabolism in Fischer 344 rats upon exposure in drinking water. Toxicol Sci 56, 282-289.

George SE, Wolf DC, Brooks LR, Bailey KC, Hooth MJ \& Rlelson GM (2004) Changes in caecal microbial metabolism of rats induced by individual and a mixture of drinking water disinfection by-products. Cancer Lett 204, 15-21.

Goldin BR (1998) Chemical induction of colon tumours in animals: an overview. Prog Clin Biol Res 279, 319-333.

Goldin BR \& Gorbach SL (1984) Alterations of the intestinal microflora by diet, oral antibiotics, and Lactobacillus: decreased production of free amines from aromatic nitro compounds, azo dyes, and glucuronides. J Natl Cancer Inst 73, 689-695.

Gorbach SL \& Goldin BR (1990) The intestinal microflora and the colon cancer connection. Rev Infect Dis 12, S252-S261.

Gusman J, Malonne H \& Atassi G (2001) A reappraisal of the potential chemopreventive and chemotherapeutic properties of resveratrol. Carcinogenesis 22, 1111-1117.

Haase P, Cowen DM, Knowles JC \& Cooper EH (1973) Evaluation of dimethylhydrazine induced tumours in mice as a model system for colorectal cancer. Br J Cancer 28, 530-543.

Hill MJ, Drasar BS, Hawksworth G, Aries V, Crowther JS \& Williams RE (1971) Bacteria and aetiology of cancer of large bowel. Lancet 16, 95-100.

Jang M, Cai L, Udeani GO, et al. (1997) Cancer chemopreventive activity of resveratrol, a natural product derived from grapes. Science 275, 218-220.

Jeandet P, Douillet-Breuil AC, Bessis R, Debord S, Sbaghi M \& Adrian M (2002) Phytoalexins from the Vitaceae: biosynthesis, phytoalexin gene expression in transgenic plants, antifungal activity, and metabolism. J Agric Food Chem 50, 2731-2741.

Johansson G, Holmen A, Persson L, Hogstedt B, Wassen C, Ottova L \& Gustafsson JA (1997) Dietary influence on some proposed risk factors for colon cancer: faecal and urinary mutagenic activity and the activity of some intestinal bacterial enzymes. Cancer Detect Prev 21, 258-266.

Kawamori T, Tanaka T, Hara A, Yamahara J \& Mori H (1995) Modifying effects of naturally occurring products on the development of colonic aberrant crypt foci induced by azoxymethane in F344 rats. Cancer Res 55, 1277-1282.

Kimura Y, Ohminami H, Okuda H, Baba K, Kozawa M \& Arichi S (1983) Effects of stilbene components of roots of Polygonum ssp. on liver injury in peroxidized oil-fed rats. Planta Med 49, 51-54. 
Kinouchi T, Kataoka K, Miyanishi K, Akimoto S \& Ohnishi Y (1993) Biological activities of the intestinal microflora in mice treated with antibiotics or untreated and the effects of the microflora on absorption and metabolic activation of orally administered glutathione conjugates of K-region epoxides of 1-nitropyrene. Carcinogenesis 14, 869-874.

Laqueur GL \& Spatz M (1968) Toxicology of cycasin. Cancer Res 28, 2262-2267.

Lowry OH, Rosebrough NJ, Farr AL \& Randall RJ (1951) Protein measurement with the Folin phenol reagent. J Biol Chem 193, $265-275$

Manju V \& Nalini N (2005) Chemopreventive efficacy of ginger, a naturally occurring anticarcinogen during the initiation, postinitiation stages of 1,2 dimethylhydrazine-induced colon cancer. Clin Chim Acta 358, 60-67.

Miller NJ \& Rice-Evans CA (1995) Antioxidant activity of resveratrol in red wine. Clin Chem 41, 1789.

Morse MA \& Stoner GD (1993) Cancer chemoprevention: principles and prospects. Carcinogenesis 14, 1737-1746.

Nalini N, Manju V \& Menon VP (2004) Effect of coconut cake on the bacterial enzyme activity in 1,2-dimethylhydrazine induced colon cancer. Clin Chim Acta 342, 203-210.

Nalini N, Sabitha K, Viswanathan P \& Menon VP (1998) Influence of spices on the bacterial (enzyme) activity in experimental colon cancer. J Ethnopharmacol 62, 15-24.

Nieuw Amerongen AV, Bolscher JG, Bloemena E \& Veerman EC (1998) Sulfomucins in the human body. Biol Chem 379, 1-18.

Nonomura S, Kanagawa H \& Makimoto A (1963) Chemical constituents of polygonaceous plants. I. Studies on the components of kojo-kon (Polygonum cuspidatum SIEB. ET ZUCC.). Yakugaku Zasshi 83, 988-990.

Reddy BS, Engle A, Simi B \& Goldman M (1992) Effect of dietary fiber on colonic bacterial enzymes and bile acids in relation to colon cancer. Gastroenterology 102, 1475-1482.

Reddy BS, Hedges AR, Laakso K \& Wynder EL (1978) Metabolic epidemiology of large bowel cancer. Cancer 42, 2832-2838.

Rembacken BJ, Snelling AM, Hawkey PM, Chalmers DM \& Axon AT (1999) Non-pathogenic Escherichia coli versus mesalazine for the treatment of ulcerative colitis: a randomized trial. Lancet 354, 635-639.

Rhodes JM, Gallimore R, Elias E \& Kennedy JF (1985) Faecal sulphatase in health and in inflammatory bowel disease. Gut 26, 466-469.
Riddell RH (1984) Dysplasia and cancer in ulcerative colitis: a soluble problem? Scand J Gastroenterol 104, 137-149.

Rowland IR, Mallett AK \& Wise A (1983) A comparison of the activity of five microbial enzymes in caecal content from rats, mice, and hamsters, and response to dietary pectin. Toxicol Appl Pharmacol 69, 143-148.

Rowland IR, Rumney CJ, Coutts JT \& Lievense L (1998) Effect of Bifidobacterium longum and carcinogen-induced aberrant crypt foci in rats. Carcinogenesis 19, 281-285.

Schneider Y, Duranton B, Gosse F, Schleiffer R, Seiler N \& Raul F (2001) Resveratrol inhibits intestinal tumourigenesis and modulates host-defense-related gene expression in an animal model of human familial adenomatous polyposis. Nutr Cancer 39, 102-107.

Seregni E, Botti C, Massaron S, Lombardo C, Capobianco A, Bogni A \& Bombardieri E (1997) Structure, function and gene expression of epithelial mucins. Tumori 83, 625-632.

Shiau SY \& Chang GW (1983) Effects of dietary fiber on faecal mucinase and $\beta$-glucuronidase activity in rats. J Nutr 113, 138-144.

Shiau SY \& Ong YO (1992) Effects of cellulose, agar and their mixture on colonic mucin degradation in rats. J Nutr Sci Vitaminol 38, $49-55$.

Shimotoyodome A, Meguro S, Hase T, Tokimitsu I \& Sakata T (2000) Decreased colonic mucus in rats with loperamide-induced constipation. Comp Biochem Physiol A Mol Integr Physiol 126, 203-212.

Simon GL \& Gorbach SL (1984) Intestinal flora in health and disease. Gastroenterology 86, 174-193.

Sporn MB \& Suh N (2000) Chemoprevention of cancer. Carcinogenesis 21, 525-530.

Tajima K, Hirose K, Nakagawa N, Kuroishi T \& Tominaga S (1985) Urban-rural difference in the trend of colo-rectal cancer mortality with special reference to the subsites of colon cancer in Japan. Jpn J Cancer Res 76, 717-728.

Tessitore L, Davit A, Sarotto I \& Caderni G (2000) Resveratrol depresses the growth of colorectal aberrant crypt foci by affecting bax and $p 21$ CIP expression. Carcinogenesis 21, 1619-1622.

Thurnherr N, Deschner EE, Stonehill EH \& Lipkin M (1973) Induction of adenocarcinomas of the colon in mice by weekly injections of 1,2-dimethylhydrazine. Cancer Res 33, 940-945.

Wattenberg LW (1985) Chemoprevention of cancer. Cancer Res $\mathbf{4 5}$, $1-8$.

Young GP \& Le Leu RK (2002) Preventing cancer: dietary lifestyle or clinical intervention? Asia Pac J Clin Nutr 11, 618-631. 